\title{
An Analysis of One Learning Styles Instrument for Language Students
}

\author{
Ann C. Wintergerst, Andrea DeCapua, \\ and Marilyn A. Verna
}

Research on learning styles focuses on how students prefer to learn. This study tested the reliability and validity of the authors' newly developed Learning Styles Indicator and explored whether reliability and validity hold true across a population of native speakers (NS) and non-native speakers (NNS) of English. This new Learning Styles Indicator was used to investigate the learning style preferences of three groups of language learners: English as a second language (ESL) students, freshman English composition students, and foreign language ( $F L)$ students. The data reveal clear learning style preferences for each of the three groups of learners. The results have classroom implications for ESL teachers, foreign language teachers, and freshman composition teachers.

La recherche portant sur les styles d'apprentissage se penche sur les diverses façons dont les étudiants préferent apprendre. Cette étude a mis à l'épreuve la fiabilité et la validité de l'outil nouvellement développé par les auteures: le "Learning Styles Indicator" (Indicateur de styles d'apprentissage) et a évalué la constance de ces deux critères chez des étudiants dont l'anglais était la langue maternelle et d'autres pour qui l'anglais était une langue étrangère. Les auteures se sont servi de l'indicateur de styles d'apprentissage pour étudier les préférences de styles d'apprentissage de trois groupes d'étudiants: des étudiants ALS, des étudiants de première année universitaire dans un cours de rédaction anglaise et des étudiants ALE. Les résultats indiquent que chaque groupe d'étudiants affichent des préférences nettes pour certains styles d'apprentissage. Les incidences de cette étude pour l'enseignement en salle de classe touchent les enseignants $A L S$, les enseignants $A L E$ et ceux qui enseignent la rédaction en première année d'université.

\section{Introduction}

Practitioners and researchers in the field of second-language teaching generally agree that individual learner differences account for the rate and the degree of success of a second-language learner (Ellis 1985). For over three decades the professional literature has been filled with discussions about learner styles, learning strategies, and personality differences (Brown, 1978; Chamot \& O'Malley, 1986; Felder \& Henriques, 1995; Moody, 1988; Oxford, 
1990, 1996; Schmeck, 1988; Skehan, 1989; Stern, 1975; Stevick, 1980; Witkin, Goodenough, \& Oltman, 1979). Research on personality differences focuses on individual characteristics that influence language learning. Salient personality factors include, but are not limited to, degrees of inhibition (Guiora, Beit-Hallami, Brannon, Dull, \& Scovel, 1972), risk-taking (Beebe, 1983), levels of anxiety (MacIntyre \& Gardner, 1991), and motivation (Oxford \& Nyikos, 1989). Learning strategies research has concerned itself with what types of mental or behavioral activities learners engage in during the learning process. Important second-language research into learning strategies has been conducted by O'Malley, Russo, and Chamot (1983); O'Malley, Chamot, Stewner-Manzanares, Kupper, and Russo (1985); O'Malley and Chamot (1990); Oxford (1990, 1996); and Tarone (1980). Oxford (1990) offers strategy inventories for both ESL learners and native speakers of English learning another language, as well as guidelines for developing one's own inventory.

Learning styles research, in which our work is centered, focuses on how students prefer to learn. Some students, for example, are visual learners who learn best when they can see (e.g., read) the material they are to learn. In an attempt to ascertain preferred learning style, numerous learning style instruments for native speakers of English have been developed. These include the Learning Style Inventory (Dunn, Dunn, \& Price, 1979, 1989), the GrashaRiechmann Student Learning Style Scales (Riechmann \& Grasha, 1974), and Kolb's $(1976,1985)$ Learning Styles Inventory. For non-native speakers of English, O'Brien's (1990) Learning Channel Preference Checklist, Oxford's (1993) Style Analysis Survey, and Reid's (1984) Perceptual Learning Style Preference Questionnaire have been developed.

Of the various learning style instruments, Reid's (1984) Perceptual Learning Styles Preference Questionnaire (PLSPQ) was the first designed for English as a second language (ESL) students at the university level. It attempts to elicit their self-reported perceptual learning style preferences. The PLSPQ consists of 30 randomly ordered statements, with five variously phrased statements for each of the six learning style preferences: visual, auditory, kinesthetic, tactile, group learning, and individual learning. Survey participants mark their responses on the basis of a five-point Likert scale ranging from strongly agree to strongly disagree.

The PLSPQ is a learning style instrument normed on both native and non-native speakers (Reid, 1987) with many teacher-researchers using it to identify their students' individual learning styles (Reid, 1995, 1998). Reid (1990) also alludes to the limitations of survey research, as does Itzen (1995) who addresses the PLSPQ in particular.

The PLSPQ was developed in two pilot studies (Reid, 1990). The first pilot test was conducted with two groups, native English speakers and ESL students. After some revision, the second pilot test was conducted solely on ESL students. According to Reid (1990), it was relatively easy to obtain reliable 
scales for the native speakers of English, but more difficult to do so for the ESL students. Of the six scales, the reliabilities were established only on two of these scales: individual learning and group learning. Reid does not mention the validity of the constructs of the survey, nor did she use any form of factor analysis to determine the validity or a corresponding factor structure for the constructs (Itzen, 1995).

Itzen (1995) undertook the assessment and validity of the PLSPQ across two groups of Hispanic college students, native English speakers, and ESL students. The results of his research indicated that the PLSPQ was not an appropriate measuring instrument for both native and non-native speakers of English. Wintergerst and DeCapua (in press) found in their study on a comparison of results from the PLSPQ and oral interviews that the results frequently did not match. The authors suggest that the discrepancies are due in large part to problems in the PLSPQ survey design. As a result of their work with the PLSPQ, Wintergerst and DeCapua initiated the development of a new learning styles instrument (Wintergerst, DeCapua, \& Itzen, 2001; Wintergerst, DeCapua, \& Verna, 2000).

\section{Earlier Studies}

\section{First Study}

Our first study, "Exploring learning styles of Russian ESL students" (1998), investigated the learning style preferences of 32 participants using Reid's PLSPQ and oral interviews in addition to a background questionnaire. The study sought answers to three questions: (a) What learning styles emerged from Reid's PLSPQ? (b) How well did the PLSPQ findings correspond with the oral interview results? (c) Did the learning style preferences reflect more individual preferences or more cultural traditions?

Of the six learning style preferences, the results showed that kinesthetic was the preferred major learning style of the Russian-speaking ESL students, closely followed by auditory. Individual work was their preferred minor learning style. Individual preferences outweighed cultural traditions. In the oral interview data gathered from a subsample of the 32 participants who completed the questionnaires, for example, there was no one major preferred learning style stated. Of the 13 participants, 4 preferred visual, 3 both visual and auditory, 2 auditory, 2 tactile, 1 both kinesthetic and visual, and 1 kinesthetic. Given that the participants in the study were previously educated in a rigid, traditional teacher-centered authoritarian system with little or no group work or student input into learning, if cultural traditions were more important than individual preferences we would expect to see conformity in choice of preferred learning style. Another explanation, however, could be the small sample of 13 students. 
The results of this first study indicated that there were discrepancies among the findings from the data elicitation instruments. The information provided by the participants during their oral interviews and their written responses on the PLSPQ contradicted each other on several occasions. Such discrepancies may have been due to English language difficulty, test-taking problems, statement design problems, culture-specific problems, influence of language proficiency on the validity and reliability of an instrument used for native and non-native speakers of English, or self-reporting issues. However, we attributed these discrepancies in large part to survey design problems in the PLSPQ. This finding prompted us to examine the construct validity of the PLSPQ in our next study.

\section{Second Study}

Our second study "Investigating methodological issues in using survey instruments" $(1999,2001)$ examined the difficulties of conceptualizing learning style modes and of developing assessment instruments that actually measure what they purport to measure. We examined the validity of the hypothesized factor structure of Reid's PLSPQ through exploratory factor analysis on a sample of 100 ESL students representing four language groups: Chinese, Korean, Russian, and Spanish. We assessed the internal consistency of these scales with the Cronbach Alpha reliability estimate and reviewed the results of both Varimax and Oblimin rotations. Subsequently, we explored an alternative learning style model through a three-factor analysis. We formed three new learning style scales: Group Orientation, Individual Activity Orientation, and Project Activity Orientation to provide a conceptually acceptable learning style framework and estimated their internal reliability as $r=.85$, $r=.77$, and $r=.65$ respectively. These scales, consisting of 24 items with the highest reliability from Reid's PLSPQ, were used to form our newly developed Learning Styles Indicator (1999).

The results of this second study indicated that the Chinese and Russian students displayed a similar pattern in their learning style preferences in that group and project activities scored higher than individual activities. Korean students expressed a slightly greater preference for individual activities and project activities than for group learning, whereas the Spanish students were oriented more toward project activities and least toward group activities.

The two earlier studies served as preliminary studies in order to establish a learning style preference questionnaire that would be suitable for students learning a new language. Having established this goal, the current study employed the same questionnaire created by study 2 to test further the reliability and validity of our Learning Styles Indicator across native and non-native speakers in three groups of students: ESL, freshman composition, and foreign language students. 


\section{Current Study}

\section{Purpose of Study}

The purpose of the current study (2000) was first, to test further the reliability and validity of the Learning Styles Indicator (LSI) and second, to explore the robustness in terms of reliability and validity across a population of nativespeakers (NS) of English and non-native speakers (NNS) of English. We explored the learning style preferences of three groups of language students: English as a Second Language (ESL) students, freshman English composition students, and foreign language (FL) students to determine their preferences for group, individual, or project orientation. In addition, we examined background variables to see if there was any significance.

The study attempted to answer the questions, Does the LSI maintain reliability and validity for native-speakers and non-native speakers of English? And second, Will the LSI factor into components for this population of students? Last, What are the learning styles for each group of students in our population?

\section{Method}

\section{Participants}

This study was conducted in two institutions of higher learning in metropolitan New York. Thirty Russian-speaking ESL students were attending one of the city colleges. All other students attended a private Catholic university. Participating in the study were 242 students or $85 \%$ of the total population polled: 98 males, 141 females, and 3 no response (see Figure 1).

They ranged in age from 17 to 66 , with a mean age of 20 . Two hundred, twenty-nine students $(95 \%)$ were undergraduates, and 13 students $(5 \%)$ were graduates. Forty-nine percent of the students were born in the United States, $16 \%$ were born in Russia, $14 \%$ in Asia, $7 \%$ in Europe, $5 \%$ in South America, $5 \%$ in the Caribbean, and $4 \%$ in other areas.

Fifty-two percent of the participants indicated English as their native language. Sixteen percent indicated Russian as their first language. The remaining $32 \%$ of the participants, in small percentages, noted Hindi, Spanish, French, Greek, Chinese, Italian, or other languages as their native tongue.

The participants were enrolled in intermediate or advanced ESL writing/reading courses, freshman English composition courses, or in foreign language (FL) courses. Seventy-three students were in ESL classes, and 34 of these were Russian (17 males and 17 females); 57 students were in freshman English composition classes; and 112 students were enrolled in FL classes40 in Italian classes, 32 in Spanish classes, 18 in French classes, 12 in Greek classes, and 10 in German classes. 


\begin{tabular}{|ll|}
\hline Participants & Native language \\
242 college/university students & $52 \%$ English \\
98 males & $16 \%$ Russian \\
141 females & $32 \%$ Hindi, Spanish, French, Greek \\
3 no responses & Chinese, Italian, and others \\
Age & Students enrolled in \\
$17-66$, mean 20 & 73 Intermediate/Advanced ESL \\
& 34 Russians (17 males, 17 females) \\
Level & \\
229 undergraduates (95\%) & 57 Freshman composition \\
13 graduates (5\%) & \\
Country of birth & 112 Foreign language \\
$49 \%$ United States & 40 Italian \\
$16 \%$ Russia & 32 Spanish \\
$14 \%$ Asia & 18 French \\
$7 \%$ Europe & 12 Greek \\
$5 \%$ South America & 10 German \\
$5 \%$ Caribbean & \\
$4 \%$ Other areas & \\
Figure 1. Study participants. & \\
\hline
\end{tabular}

\section{Materials}

\section{Operational Definitions}

Learning styles. These are the tendencies or preferences of individuals with respect to how they learn. They are internally based characteristics that Ehrman and Oxford (1990) define as "preferred or habitual patterns of mental functioning and dealing with new information" (p. 311). Some individuals prefer to hear information, others prefer to read it, and still others prefer to do something with it.

The three learning style dimensions used in this study refer to specific types of style characteristics and do not cover cognitive learning styles that are focal issues in mainstream learning style research (e.g., holistic/global, analytic, etc.). The selected dimensions were conceptualized modes resulting from statements with the highest reliability drawn from Reid's PLSPQ in our earlier study.

Project Orientation (PO) Scale. This scale refers to a student's preference of learning best when he or she is involved in tactile or kinesthetic activities when working in a learning situation. The student may be working individually or with others.

Group Activity Orientation (GAO) Scale. This scale refers to a student's preference of learning best when he or she is interacting or working with one or more students in a learning situation. 
Individual Activity Orientation (IAO) Scale. This scale refers to a student's preference of learning best when he or she is working alone in a learning situation.

To understand operationally the meaning of these scales, it is useful to examine some of the items that make up each scale (see Appendix A). For example, the PO scale (11 items) measures whether the student learns best when performing a hands-on activity. A student with high scores on this scale always agrees or very often agrees with such statements as, \#20 "I learn more when I make something for a class project" or \#3 "I understand things better in class when I participate in role playing." A high score is achieved for the GAO scale ( 5 items) if the student always agrees or very often agrees with such statements as, \#18 "I prefer to study with others" or \#1 "I enjoy working on an assignment with two or three classmates." These items suggest a student who prefers to interact with others when learning. For the IAO scale ( 7 items), a high score is achieved when a student always agrees or very often agrees with these statements, \#23 "I learn better by reading than by listening to someone" or \#5 "When I study alone, I remember things better." These items suggest a student who prefers learning by himself or herself.

Non-native speakers (NNS) of English. Students whose first language is other than English; these students could be enrolled in freshman composition classes, ESL classes, or foreign language classes.

Native speakers (NS) of English. Students whose first language is English, whether born in the US or elsewhere; these students could be enrolled in freshman composition classes or foreign language classes.

Foreign language group $(F L)$. These were students enrolled in foreign language classes: Italian, Spanish, French, Greek, and German.

\section{Design and Procedure}

A packet of materials was sent to each participating professor. This included an introductory letter explaining the purpose of the study and the procedures for the professor's participation, one Learning Styles Indicator (LSI) survey instrument (see Appendix B) for every student, one background questionnaire for every student, and a self-addressed envelope. During class time students were asked to complete the surveys based on how they were developing their English writing skills. There were two exceptions. If students were in a foreign language class other than ESL, they were instructed to complete the survey based on their foreign language learning experiences. If English was not their native language as is the case with ESL students, they were asked to complete the survey based on how they had learned English both in the US and in their home country.

The students were asked to complete the LSI based on the Learning Styles Indicator Scales developed by Wintergerst and DeCapua (1999), which conceptualizes three learning styles (PO, GAO, and IAO). The 24 statements, 
originally drawn from Reid's (1984) PLSPQ, were designed to identify a student's learning style preference. These statements were randomly ordered on the new LSI. Participants were given four choices (a. always, b. very often, c. sometimes, d. never) to express their degree of agreement or disagreement with each statement in lieu of the five-point Likert scale used in the PLSPQ. To discourage students from selecting the middle response in a five-point Likert scale, it was changed to four choices. The scaling of answers was as follows: always $=1$, very often $=2$, sometimes $=3$, and never $=4$.

Caution must be taken when administering a self-report instrument. The researcher can never be sure that the individual is expressing a true interest (Gay \& Airasian, 2000). The instructors administering these questionnaires emphasized with the students the importance of responding honestly to their language learning experience whether as a native or non-native speaker of English.

Each student was also asked to complete a background questionnaire of general demographic information such as languages spoken, language being learned, proficiency in that language compared with that of a native speaker's, and parents' occupation and education. For non-native speakers the length of time English was studied in the native country and at home and the student's home country were asked. The researchers hoped to find a relationship between the number of languages spoken and the learning styles. Unfortunately, not enough information was obtained for other languages spoken; therefore, no statistical results are reported.

\section{Results}

\section{Validity and/or Reliability}

The instrument used in this study was developed from a pilot study with NNS and NS of English. Separate Principal Component analyses were calculated to isolate the factors for NNS and NS. These tests were conducted to construct an instrument that could be used with cross-cultural samples.

The initial step in the analysis of the data was to factor analyze the questionnaire as a whole unit. Each foreign language student's questionnaire answers were factor analyzed. The chosen method used to extract maximum variance from the data and to verify the factor structure for the foreign language students was Principal Component (PC) analysis. Criteria for the stability of the PC analysis extraction depend on a large sample, numerous variables, and similar and high communality estimates (Tabachnick \& Fidell, 2001). An estimate of PCs was also determined by the size of the eigenvalues. The scree test (Catell, 1966) of eigenvalues plotted against PCs was examined. Gorsuch (1983) reports that the results of the scree test are more obvious and reliable when sample size is large, communality values are high, and each PC has several variables with high loadings. The extracted data 
from the present study are in agreement with these requirements. A rotated PC matrix was generated yielding unit weighted PC scores. The Varimax rotation procedure maximized the variance of the loadings within $P C$ and across variables, thereby creating a set of interpretable scales.

Variables with loadings of .30 and above provide for meaningful correlation and are interpretable (Tabachnick \& Fidell, 2001). Comrey (1973) suggests that loadings in excess of .71 are considered excellent, .63 very good, .55 good, .45 fair, and .32 low. Choice of the cutoff for the size of factor loadings to be interpreted is a matter of researcher preference (Tabachnick \& Fidell, 2001). In this study the cutoff point was selected to be greater than .30. Based on these criteria, the initial PC analysis resulted in question item \#21, "I prefer working on projects by myself" producing a low loading coefficient (.30); therefore, it was eliminated from the scale. PC analysis in the previous study and in the current study extracted the initially designed three factors: $\mathrm{PO}, \mathrm{GAO}$, and IAO.

Following the PC analyses, each measurement scale underwent an item analysis that produced variable means, standard deviations (see Table 1),

Table 1

Variable Means and Standard Deviations

\begin{tabular}{lcc}
\hline Variable & Mean & Standard Deviation \\
\hline Project Orientation (PO) & 2.37 & .52 \\
Group Activity Orientation (GAO) & 2.66 & .52 \\
Individual Activity Orientation (IAO) & 2.22 & .49 \\
Years of Studying English in Native Country* & 1.36 & 3.30 \\
\hline
\end{tabular}

*Based on participants born in a country other than the US.

Table 2

Pearson Correlation Coefficients Between Learning Styles and Background Variables

\begin{tabular}{lccc}
\hline Variable & $\begin{array}{c}\text { Group Activity } \\
\text { Orientation }\end{array}$ & $\begin{array}{c}\text { Individual Activity } \\
\text { Orientation }\end{array}$ & $\begin{array}{c}\text { Project } \\
\text { Orientation }\end{array}$ \\
\hline Years of Studying English in & & & \\
Native Country & -.02 & $-.20^{* *}$ & $-.14^{*}$ \\
Language Being Learned & -.07 & $-.20^{* *}$ & $-.17^{\star *}$ \\
\hline
\end{tabular}

${ }^{*} p<.05$.

${ }^{\star *} p<.01$.

${ }_{\star \star *}$ Based on participants born in a country other than the US. 
Table 3

Rotated Factor Matrix for the Study's Questionnaire Data

\begin{tabular}{|c|c|c|c|}
\hline \multirow[t]{2}{*}{ Question Number } & \multicolumn{3}{|c|}{ Factors and Factor Loadings } \\
\hline & $1^{*}$ & $2^{\star \star}$ & $3^{\star \star \star}$ \\
\hline Q20 & .75 & & \\
\hline Q16 & .71 & & \\
\hline Q3 & .68 & & \\
\hline Q24 & .66 & & \\
\hline Q10 & .65 & & \\
\hline Q7 & .63 & & \\
\hline Q2 & .60 & & \\
\hline Q4 & .59 & & \\
\hline Q13 & .57 & & \\
\hline Q19 & .41 & & \\
\hline Q15 & .33 & & \\
\hline Q18 & & .82 & \\
\hline Q22 & & .79 & \\
\hline Q11 & & .75 & \\
\hline Q6 & & .73 & \\
\hline Q1 & & .67 & \\
\hline Q23 & & & .72 \\
\hline Q12 & & & .70 \\
\hline Q5 & & & .53 \\
\hline Q14 & & & .52 \\
\hline Q8 & & & .51 \\
\hline Q17 & & & .46 \\
\hline Q9 & & & .43 \\
\hline
\end{tabular}

Q21 did not have a loading of .30 or greater on any factor.

*Project Orientation Scale.

**Group Activity Orientation Scale.

${ }^{* * *}$ Individual Activity Orientation Scale.

and an inter-item correlation matrix. The Pearson correlation coefficient matrix between learning styles and background variables is presented in Table 2.

Alpha reliability coefficients were calculated for each of the three scales. Reliabilities were as follows: PO Scale $r=.84$, GAO Scale $r=.86$, IAO Scale $r=.73$. Additional procedures were conducted to detect outliers, the assumption of homoscedasticity, normality, and linearity. All assumptions were met.

The required sample size of 50 is adequate if there are strong, reliable correlations and a few distinct factors (Tabachnick \& Fidell, 2001). The ESL classes and the freshman English composition classes satisfied these conditions. Similar PCs were revealed for these two groups. The alpha reliability 
Table 4

Rotated Factor Matrix for ESL Questionnaire Data

\begin{tabular}{|c|c|c|c|}
\hline \multirow[t]{2}{*}{ Question Number } & \multicolumn{3}{|c|}{ Factors and Factor Loadings } \\
\hline & $1^{*}$ & $2^{\star \star}$ & $3^{\star \star \star}$ \\
\hline Q17 & .74 & & \\
\hline Q20 & .70 & & \\
\hline Q16 & .69 & & \\
\hline Q3 & .65 & & \\
\hline Q24 & .59 & & \\
\hline Q2 & .59 & & \\
\hline Q10 & .58 & & \\
\hline Q7 & .57 & & \\
\hline Q13 & .57 & & \\
\hline Q4 & .50 & & \\
\hline Q9 & .39 & & \\
\hline Q18 & & .87 & \\
\hline Q11 & & .80 & \\
\hline Q6 & & .79 & \\
\hline Q22 & & .71 & \\
\hline Q1 & & .61 & \\
\hline Q19 & & .53 & \\
\hline Q15 & & .50 & \\
\hline Q8 & & & .78 \\
\hline Q5 & & & .76 \\
\hline Q12 & & & .67 \\
\hline Q23 & & & .56 \\
\hline Q14 & & & .54 \\
\hline
\end{tabular}

Q21 did not have a loading of .30 or greater on any factor.

*Project Orientation Scale.

**Group Activity Orientation Scale.

${ }^{* * *}$ Individual Activity Orientation Scale.

coefficients were calculated, yielding good estimates for each Principal Component and ranged from $r=.75$ to $r=.86$.

PC analysis revealed three PC scales: Project Orientation (PO), Group Activity Orientation (GAO), and Individual Activity Orientation (IAO) as presented in Table 3.

This outcome is in line with earlier research by Wintergerst et al. (1999), although the distribution of items under each of the three PCs differs. The 73 ESL students and the 57 freshman English composition students revealed similar results with each other and with the analysis of the entire population. However, for the ESL students the PO scale included questions 9 and 17, whereas questions 15 and 19 loaded on the GAO scale (see Table 4). 
Table 5

Rotated Factor Matrix for Freshman English Composition Questionnaire Data

\begin{tabular}{|c|c|c|c|}
\hline \multirow[t]{2}{*}{ Question Number } & \multicolumn{3}{|c|}{ Factors and Factor Loadings } \\
\hline & $1^{*}$ & $2^{\star *}$ & $3^{\star \star \star}$ \\
\hline Q3 & .80 & & \\
\hline Q7 & .71 & & \\
\hline Q20 & .70 & & \\
\hline Q4 & .69 & & \\
\hline Q24 & .66 & & \\
\hline $\mathrm{Q} 2$ & .66 & & \\
\hline Q10 & .58 & & \\
\hline Q16 & .56 & & \\
\hline Q13 & .56 & & \\
\hline Q15 & .52 & & \\
\hline Q22 & & .83 & \\
\hline Q18 & & .82 & \\
\hline Q6 & & .67 & \\
\hline Q11 & & .57 & \\
\hline Q1 & & .54 & \\
\hline Q17 & & & .80 \\
\hline Q19 & & & .67 \\
\hline Q9 & & & .64 \\
\hline Q8 & & & .58 \\
\hline Q23 & & & .53 \\
\hline Q5 & & & .52 \\
\hline Q14 & & & .43 \\
\hline Q12 & & & .38 \\
\hline
\end{tabular}

Q21 did not have a loading of .30 or greater on any factor.

*Project Orientation Scale.

**Group Activity Orientation Scale.

$* * *$ Individual Activity Orientation Scale.

For the freshman English composition participants, question 19 loaded on the IAO scale (see Table 5).

The data from the Italian, Spanish, French, Greek, and German FL classes were grouped together (see Table 6). PC analysis was conducted. The results were in accordance with the analysis of the entire population with the exception of question 15, which loaded on the IAO scale for the FL group.

The data were then analyzed according to NNS of English and NS of English. PC analysis for the NNS was in agreement with the analysis of the entire population with the exception of question 19, which loaded on the GAO scale (see Table 7). This loading was in agreement with the ESL population results. 
Table 6

Rotated Factor Matrix for Foreign Language Questionnaire Data

\begin{tabular}{|c|c|c|c|}
\hline \multirow{2}{*}{ Question Number } & \multicolumn{2}{|c|}{ Factors and Factor Loadings } & \multirow[b]{2}{*}{$3^{* * *}$} \\
\hline & & & \\
\hline Q16 & .79 & & \\
\hline Q20 & .74 & & \\
\hline Q10 & .71 & & \\
\hline Q3 & .69 & & \\
\hline Q7 & .67 & & \\
\hline Q24 & .66 & & \\
\hline Q4 & .64 & & \\
\hline Q2 & .60 & & \\
\hline Q13 & .50 & & \\
\hline Q19 & .39 & & \\
\hline Q18 & & .85 & \\
\hline Q11 & & .83 & \\
\hline Q22 & & .82 & \\
\hline Q6 & & .74 & \\
\hline Q1 & & .74 & \\
\hline Q12 & & & .76 \\
\hline Q23 & & & .74 \\
\hline Q9 & & & .54 \\
\hline Q14 & & & .47 \\
\hline Q17 & & & .45 \\
\hline Q15 & & & .42 \\
\hline Q5 & & & .39 \\
\hline Q8 & & & .34 \\
\hline
\end{tabular}

Q21 did not have a loading of 30 or greater on ary factor.

*Project Orientation Scale.

**Group Activity Orientation Scale.

${ }^{\star \star \star}$ Individual Activity Orientation Scale.

PC analysis for NS yielded partly different results (see Table 8). Question 19 loaded on the IAO scale, which was similar to the freshman English composition class. Because questions 5, 12, 14, 15, and 23 yielded extremely low factor loadings, they were not placed with any of the three factors.

Pearson Product Correlations were executed between the three PC scales and each of the background variables for the total population of study participants (see Table 2). The discrete variable of language being learned was first converted into a set of dichotomous variables by dummy variable coding where English equals 1 and all the other languages equal 0 (Tabachnick \& Fidell, 2001). Only two factors and two variables resulted in significance. Significant negative correlations were revealed between the language being learned (English, Spanish, Italian, French, Greek, and Ger- 
Table 7

Rotated Factor Matrix for the Non Native Speakers of English

Questionnaire Data

\begin{tabular}{|c|c|c|c|}
\hline \multirow[t]{2}{*}{ Question Number } & \multicolumn{3}{|c|}{ Factors and Factor Loadings } \\
\hline & $1^{*}$ & $2^{\star \star}$ & $3^{\star \star *}$ \\
\hline Q3 & .76 & & \\
\hline Q20 & .71 & & \\
\hline Q16 & .68 & & \\
\hline Q2 & .65 & & \\
\hline Q7 & .62 & & \\
\hline Q24 & .62 & & \\
\hline Q10 & .60 & & \\
\hline Q13 & .58 & & \\
\hline Q4 & .57 & & \\
\hline Q18 & & .85 & \\
\hline Q22 & & .82 & \\
\hline Q6 & & .79 & \\
\hline Q11 & & .76 & \\
\hline Q1 & & .70 & \\
\hline Q19 & & .37 & \\
\hline Q12 & & & .76 \\
\hline Q23 & & & .72 \\
\hline Q17 & & & .58 \\
\hline Q5 & & & .55 \\
\hline Q9 & & & .55 \\
\hline Q8 & & & .50 \\
\hline Q14 & & & .39 \\
\hline Q15 & & & .33 \\
\hline
\end{tabular}

Q21 did not have a loading of .30 or greater on any factor.

*Project Orientation Scale.

**Group Activity Orientation Scale.

***Individual Activity Orientation Scale

man and the IAO scale (-.20) and the PO scale (-.17). In other words, because the total population of the study did not show a positive preference for individual work or project work, we can infer that the students prefer to learn a language in some other way. Significant negative correlations were also revealed for the number of years English was studied in the student's home country and the IAO scale (-.20) and the PO scale (-.14). Seemingly, the longer NNS of English had studied English as a foreign language in their home country, the less they indicated a preference for individual or project work. It is in the interpretation of the negative correlation that explains the difference in groups. Analysis of Variance (ANOVA) procedures were performed on the learning style means in order to detect differences among the 
Table 8

Rotated Factor Matrix for the Native Speakers of English

Questionnaire Data

\begin{tabular}{|c|c|c|c|}
\hline \multirow[t]{2}{*}{ Question Number } & \multicolumn{3}{|c|}{ Factors and Factor Loadings } \\
\hline & $1^{*}$ & $2^{* *}$ & $3^{\star \star *}$ \\
\hline Q3 & .78 & & \\
\hline Q24 & .73 & & \\
\hline Q16 & .73 & & \\
\hline Q20 & .71 & & \\
\hline Q2 & .69 & & \\
\hline Q10 & .65 & & \\
\hline Q4 & .64 & & \\
\hline Q7 & .58 & & \\
\hline Q13 & .49 & & \\
\hline Q18 & & .76 & \\
\hline Q22 & & .72 & \\
\hline Q11 & & .65 & \\
\hline Q1 & & .60 & \\
\hline Q6 & & .56 & \\
\hline Q17 & & & .78 \\
\hline Q19 & & & .76 \\
\hline Q9 & & & .73 \\
\hline Q8 & & & .34 \\
\hline
\end{tabular}

Q5, Q12, Q14, Q15, Q21, and Q23 did not have loadings of .30 or greater on any factor.

* Project Orientation Scale.

${ }^{* *}$ Group Activity Orientation Scale.

${ }^{* \star *}$ Individual Activity Orientation Scale.

language classes. No significant differences were found between the different language groups on the GAO or the IAO. However, a significant difference was detected between the PO and the language classes: $F(6,235)=$ $2.352, p<.05$. Further analysis employing Tukey Post-Hoc procedures revealed a significant finding between the ESL and the freshman English composition classes. The FL classes did not prove to be significant.

\section{Discussion}

This study does not provide a comprehensive analysis of the measurement of learning styles as this was not its goal. Nor does it provide a comprehensive analysis of the measurement of learning style, as this too was not its goal. The instrument proposed focuses on one specific aspect of the style construct, and it is in this area that a contribution is offered.

PC analysis showed that the study participants learn English or a foreign language in PO, GAO, and IAO situations. Question 19 of the LSI, "When the 
teacher tells me the instructions, I understand better" loaded on different scales for ESL students, freshman English composition students, NS of English and NNS of English. For ESL students and NNS, question 19 was included in the GAO scale. For the freshman English composition students and the NS, question 19 was included in the IAO scale. It seems that the ESL students and NNS tend to consider the teacher as part of the learning process, making the question fall into the group scale, whereas the freshman English composition students and NS tend to consider the teacher as a facilitator of instruction and not part of the learning process. Similar reasoning would apply to question 15, "When someone tells me how to do something in class, I learn better." For the ESL and freshman English composition students, this statement, like question 19, loaded on the GAO and IAO scales respectively.

Dummy variable coding resulted in negative correlations. It is the interpretation of the negative correlation that explains the difference in groups. Students learning English, both NS and NNS of English, and those who studied English in their home country for many years did not like to work individually or on projects, whereas the students learning a foreign language (Italian, Spanish, French, Greek, and German) preferred working individually and on projects. It seems logical that if significance were revealed for IAO and $\mathrm{PO}$, then students would prefer GAO. Although significance was not revealed for the GAO scale, the negative results for students learning English with the IAO and PO scales would indicate that group work, with the lowest negative correlation, might be preferred by these students.

The ANOVA post-hoc results between PO and the language groups showed that the freshman English composition students had a higher mean score on the PO scale than the ESL students. Students in freshman English composition tend to have a better command of the English language and, therefore, might be more likely to work on projects. Working on projects might require more research and reading. Students enrolled in freshman English composition classes are simultaneously taking other university courses and are more likely to be exposed to US teaching methods that encourage group and project work in contrast to the traditional teachercentered learning popular in many other countries (Gorsuch, 2000; Scarcella, 1990).

In short, the results from the ESL population in this study appear to fall in line with earlier research by Wintergerst and DeCapua (1998) and Wintergerst et al. (1999, 2001). The 1998 study found that this group of Russian-speaking ESL students preferred kinesthetic and auditory learning styles with individual work as a minor preference, the 1999 study with a different group of Russian-speaking ESL students that they preferred group and project orientation, and the current study with still another group of Russian-speaking ESL students that they preferred more group orientation 
than individual or project orientation. As a whole, these results seem to suggest that Russian-speaking ESL students tend to have similar but distinct learning styles. Although these three groups of ESL students shared the same first language, they differed from one another in preferred learning styles. The studies revealed that individual preferences were more important than cultural influences in learning style preferences.

Finally, the results in the current study showed that freshman English composition students preferred project orientation, as evidenced by the ANOVA results, whereas FL students preferred project and individual orientation but not group orientation, as shown by the correlations presented.

\section{Implications}

The results of this study suggest possible directions for ESL teachers, foreign language teachers, and freshman composition teachers. Teachers of ESL students might consider focusing more on group activities and deemphasizing individual and project work. With respect to classroom dynamics, ESL teachers could be more effective in the classroom if they were aware that the teacher may be viewed as part of the group rather than as a lecturer or facilitator of instruction.

On the other hand, the results of this study indicated that foreign language students prefer individual and project work rather than group work. Therefore, FL teachers might focus more on activities designed for individual and project work. Similarly, freshman English composition students prefer project work. Regardless of whether this preference has to do with these students' greater English language facility, teachers of freshman English composition courses could consider incorporating more project activities into their lessons.

Because students learn best when they are actively involved in the learning process (Gardner, 1983), teachers are more likely to reach most, if not all, students by using teaching strategies that correspond to their students' learning styles. As Omaggio Hadley (1993) posits,

By helping students to become aware of their own strategies and learning preferences, as well as guiding them expertly to become effective and autonomous learners as they approach various learning tasks, teachers can go a long way toward accommodating individual learner needs more effectively. (p. 67)

\section{The Authors}

Ann $C$. Wintergerst is an associate professor of TESOL in the Department of Languages and Literatures at St. John's University, New York. She received her EdD in TESOL from Teachers College, Columbia University. She is the author of Second Language Classroom Interaction (University of Toronto Press, 1994) and editor of Focus on Self-Study: Evaluating Post-secondary ESOL 
Programs (TESOL, 1995). Her articles have also appeared in College ESL, System, and the CATESOL Journal.

Andrea DeCapua earned her EdD in applied linguistics from Teachers College, Columbia University. She has published in the areas of pragmatics and language learning and sociolinguistics in such journals as Multilingua, Journal of Pragmatics, Issues in Applied Linguistics, System, and the CATESOL Jounal.

Marilyn Ann Verna is an assistant professor of education at St. Francis College, New York. She received her EdD in instructional leadership from St. John's University. She is the author of several articles on gifted studies and international studies. She has published articles in the Journal of Secondary Gifted Education, TEMPO, Gifted and Talented International, and the Journal of Research in Education.

\section{References}

Beebe, L. (1983). Risk-taking and the language learner. In H. Seliger \& M. Long (Eds.), Classroom oriented research in second language acquisition. Rowley, MA: Newbury House.

Brown, R. (1978). The effects of congruency between learning styles and teaching styles on college student achievement. College Student Journal, 12, 307-309.

Catell, R.B. (1966). The scree test for the number of factors. Multivariate Behavioral Research, 1 , 245-276.

Comrey, A.L. (1973). A first course in factor analysis. New York: Academic Press.

Chamot, A., \& O'Malley, J. (1986). Cognitive Academic Language Learning Approach: An ESL content-based curriculum. Rosslyn, VA: National Clearinghouse for Bilingual Education and InterAmerican Research Associates.

Dunn, R.S., Dunn, K., \& Price, G.E. (1979). Identifying individual learning styles. In J. Keefe (Ed.), Student learning styles: Diagnosing and prescribing programs (pp. 39-54). Reston, VA: National Association of Secondary School Principals.

Dunn, R.S., Dunn, K., \& Price, G.E. (1989). Learning styles inventory (LSI): An inventory for the identification of how individuals in grades 3 through 12 prefer to learn. Lawrence, KS: Price Systems.

Ellis, R. (1985). Understanding second language acquisition. Oxford, UK: Oxford University Press.

Ehrman, M.E., \& Oxford, R. (1990). Adult language learning styles and strategies in an intensive training setting. Modern Language Journal, 74, 311-327.

Felder, R.M., \& Henriques, E.R. (1995). Learning and teaching styles in foreign and second language education. Foreign Language Annals, 28, 21-33.

Gardner, H. (1983). Frames of minds: The theory of multiple intelligences. New York: Basic Books.

Gay, L.R., \& Airasian, P. (2000). Educational research: Competencies for analysis and application (6th ed). Upper Saddle Ricer, NJ: Merrill.

Gorsuch, G.J. (2000). EFL educational policies and educational cultures: Influences on teachers' approval of communicative activities. TESOL Quarterly, 34, 675-710

Gorsuch, R.L. (1983). Factor analysis. Hillsdale, NJ: Erlbaum.

Guiora, A., Beit-Hallami, B., Brannon, R., Dull, C., \& Scovel, T. (1972). The effects of experimentally induced changes in ego states on pronunciation ability in second language:

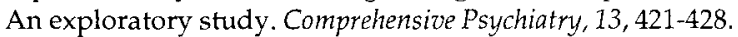

Itzen, R. (1995). The dimensionality of learning structures in the Reid perceptual learning style preference questionnaire. Unpublished doctoral dissertation, University of Illinois at Chicago.

Kolb, D. (1976). The learning style inventory: Self-scoring test and interpretation. Boston, MA: McBer.

Kolb, D. (1985). Learning style inventory (rev. ed.). Boston, MA: McBer.

Maclntrye, P., \& Gardner, R. (1991). Language anxiety: Its relationship to other anxieties and to processing in native and second languages. Language Learning, 41, 513-534. 
Moody, R. (1988). Personality preferences and foreign language learning. Modern Language Joumal, 72, 389-401.

O'Brien, L. (1990). Learning channel preference checklist. Rockville, MD: Specific Diagnostic Services.

Omaggio Hadley, A. (1993). Teaching language in context. Boston, MA: Heinle \& Heinle.

O'Malley, J., \& Chamot, A. (1990). Learning strategies in second language acquisition. New York: Cambridge University Press.

O'Malley, J., Russo, R., \& Chamot, A. (1983). A review of the literature on learning strategies in the acquisition of English as a second language. The potential for research applications. Rosslyn, VA: InterAmerica Research Associates.

O’Malley, J., Chamot, A., Stewner-Manzanares, Kupper, L., \& Russo, R. (1985). Learning strategies used by beginning and intermediate ESL students. Language Learning, 35, 21-46.

Oxford, R.L. (1990). Language learning strategies: What every teacher should know. New York: Newbury House/Harper \& Row.

Oxford, R.L. (1993). Style analysis survey. Tuscaloosa, AL: University of Alabama.

Oxford, R.L. (Ed.). (1996). Language learning strategies around the world: Cross-cultural perspectives. Manoa, HI: University of Hawai'i at Manoa.

Oxford, R., \& Nyikos, M. (1989). Variables affecting choice of language learning strategies by university students. Modern Language Journal, 73, 291-300.

Reid, J. (1984). Perceptual Learning Styles Preference Questionnaire Available from J. Reid, Department of English, University of Wyoming, Laramie, WY 82070.

Reid, J. (1987). The perceptual learning style preferences of ESL students. TESOL Quarterly, 21, 87-111.

Reid, J. (1990). The dirty laundry of ESL survey research. TESOL Quarterly, 24, 323-338.

Reici, J. (1995). Learning styles in the ESL/EFL classroom. Boston, MA: Heinle \& Heinle.

Reid, J. (1998). Understanding learning styles in the second language classroom. Upper Saddle River, NJ: Prentice-Hall Regents.

Riechmann, S., \& Grasha, A. (1974). A rational approach to developing and assessing the construct validity of the Student Learning Style Scales Instrument. Journal of Psychology, 87, 213-223.

Scarcella, R.C. (1990). Teaching language minority students in the multicultural classroom. Englewood Cliffs, NJ: Prentice-Hall.

Skehan, P. (1989). Individual differences in second-language learning. London: Edward Arnold.

Schmeck, R. (1988). Learning strategies and learning styles. New York: Plenum.

Stern, H.H. (1975). What can we learn from the good language learner? Canadian Language Review, 31, 304-318.

Stevick, E. (1980). Teaching languages: A way and ways. Rowley, MA: Newbury House.

Tabachnick, B.G., \& Fidell, L.S. (2001). Using multivariate statistics. New York: Harper \& Row.

Tarone, E. (1980). Communication strategies, foreigner talk, and repair in interlanguage. Language Learning, 30, 417-431.

Wintergerst, A.C., \& DeCapua, A. (1998, March). Exploring learning styles of Russian ESL students. Paper presented at the 32nd Annual TESOL Convention, Seattle.

Wintergerst, A.C., \& DeCapua, A. (in press). Exploring the learning styles of Russian-speaking ESL students. CATESOL Journal.

Wintergerst, A.C., \& DeCapua, A. (1999). Learning Styles Indicator (LSI). Available from A. Wintergerst, Department of Languages and Literatures, St. John's University, 70-15 71st Place, Glendale, NY 11385.

Wintergerst, A.C., DeCapua, A., \& Itzen, R. (1999, March). Investigating methodological issues in using survey instruments. Paper presented at the American Association for Applied Linguistics Annual Conference, Stamford.

Wintergerst, A.C., DeCapua, A., \& Itzen, R. (2001). The construct validity of one learning styles instrument. System, 29,385-403. 
Wintergerst, A.C., DeCapua, A., \& Verna, M. (2000, March). Elicitation instruments, learning styles and ESL/FL students. Paper presented at the American Association for Applied Linguistics Annual Conference, Vancouver.

Witkin, H., Goodenough, D., \& Oltman, P. (1979). Psychological differentiation: current status. Journal of Personality and Social Psychology, 37, 1127-1145.

\section{Appendix A}

\section{Learning Styles Indicator Scales}

\section{Learning Style One: Project Orientation}

Q20 I learn more when I can make something for a class project.

Q16 I enjoy making something for a class project.

Q3 I understand things better in class when I participate in role playing.

Q24 I prefer to learn by doing something in class.

Q10 When I build something, I remember what I have learned better.

Q7 I enjoy learning in class by doing experiments.

Q2 I learn best in class when I can participate in related activities.

Q4 I learn more when I can make a model of something.

Q13 When I do things in class, I learn better.

Q19 When the teacher tells me the instructions, I understand better.

Q15 When someone tells me how to do something in class, I learn better.

\section{Learning Style Two: Group Activity Orientation}

Q18 I prefer to study with others.

Q22 I learn more when I study with a group.

Q11 In class, I learn best when I work with others.

Q6 I get more work done when I work with others.

Q1 I enjoy working on an assignment with two or three classmates.

\section{Learning Style Three: Individual Activity Orientation}

Q14 I prefer to work by myself.

Q8 When I work alone, I learn better.

Q23 I learn better by reading than by listening to someone.

Q12 I learn more by reading textbooks than by listening to lectures.

Q5 When I study alone, I remember things better.

Q17 When I read instructions, I remember them better.

Q9 I understand better when I read instructions.

Did not have a loading of .30 or greater on any factor:

Q21 I prefer working on projects by myself.

Statements drawn from Reid (1984) 


\section{Appendix B \\ Learning Styles Indicator}

Age Sex Native Language

Circle your answer for each statement.

- Please complete the survey based upon how you are developing your English writing skills.

- If you are studying a foreign language, please complete the survey based upon your foreign language learning experiences.

- If English is not your native language, please complete the survey based upon how you learned English both here and in your home country.

1. I enjoy working on an assignment with Always Very Often Sometimes Never two or three classmates.

2. I learn best in class when I can participate in related activities.

3. I understand things better in class when I participate in role playing.

4. I learn more when I can make a model of something.

5. When I study alone, I remember things better.

6. I get more work done when I work with others.

7. I enjoy learning in class by doing experiments.

8. When I work alone, I learn better.

9. I understand better when I read instructions.

10. When I build something, I remember what I have learned better.

11. In class, I learn best when I work with others.

12. I learn more by reading textbooks than by listening to lectures.

13. When I do things in class, $I$ learn better.

14. I prefer to work by myself.

15. When someone tells me how to do something in class, I learn better.

16. I enjoy making something for a class project.

17. When I read instructions, I remember them better.

18. I prefer to study with others.

19. When the teacher tells me the instructions I understand better.

20. I learn more when I can make something for a class project.

Always Very Often Sometimes Never

Always Very Often Sometimes Never

Always Very Often Sometimes Never

Always Very Often Sometimes Never

Always Very Often Sometimes Never

Always Very Often Sometimes Never

Always Very Often Sometimes Never

Always Very Often Sometimes Never

Always Very Often Sometimes Never

Always Very Often Sometimes Never

Always Very Often Sometimes Never

Always Very Often Sometimes Never

Always Very Often Sometimes Never

Always Very Often Sometimes Never

Always Very Often Sometimes Never

Always Very Often Sometimes Never

Always Very Often Sometimes Never

Always Very Often Sometimes Never

Always Very Often Sometimes Never

Always Very Often Sometimes Never 
22. I learn more when I study with a group.

23. I learn better by reading than by listening to someone.

24. I prefer to learn by doing something in class.

Statements drawn from Reid (1984)
Always Very Often Sometimes Never

Always Very Often Sometimes Never

Always Very Often Sometimes Never 